\title{
Climate change, its impact and adaptation strategies on agriculture in Mangaltar, Khotang District, Nepal
}

\author{
Manisha Rai ${ }^{1}$ Prem Sagar Chapagain ${ }^{2}$
}

\begin{abstract}
Climate change is one of the crucial and inevitable issues in the earth though people can minimize on contribution and can adapt coping strategies. Although, Nepal contributes very less part of the total in the factors of climate change, local people are observing significant changes which leading many challenges. As a result, the livelihood of local people is being more critical. Based on the data collected from the 7 wards of Mangaltar VDC in Khotang district, the result shows the changing pattern indicators of climate change and its impact on crops production. In addition, the findings illustrate the local adaptation strategies on changing environment in the period of last thirty years.
\end{abstract}

Key words: Climate change, agriculture, perception, production, pattern, adaptation

\section{Introduction}

Nepal is predominantly agricultural country. Over 66 percent of the economically active population involve in agriculture. Agriculture contributes 27.6 percent in the GDP (MoF, 2018), it supports livelihoods of 83 percent of total population (CBS, 2011). Agricultural production is largely affected by climate change.

The average annual temperature in Nepal has increased from $0.04^{0}-0.06^{\circ} \mathrm{C}(\mathrm{MoE}$, 2010). According to the observed climate trend analysis with the data of over more than 40 years (1971-2014) by Department of Hydrology and Meteorology (DHM), the annual maximum temperature trend is significantly increased by $0.056^{\circ} \mathrm{C} /$ year, and annual minimum temperature trend has also changed by $0.002^{\circ} \mathrm{C} /$ year in Nepal (DHM, 2017). Seasonal and annual maximum temperature trends demonstrate a pattern in relation to altitude with negative trend or small positive trend in lower altitude and larger positive trend in higher altitude in the both at district and

${ }^{1}$ Corresponding author; e-mail: manisha.geog@gmail.com
2 Professor, Central Department of Geography, Tribhuvan University, Kathmandu, Nepal. 
physiographic levels. However, Number of rainy days is increasing significantly mainly in the northwestern districts (DHM, 2017).

Most of the agriculture areas, particularly in the Hilly region are rain-fed. Thus, any changes in rainfall and air temperature bring significant changes in agricultural production. At the same time, the climatic changes affect the grassland, fodder production and productivity that may result changes in livestock breeding and production system. The observed extreme weather events between 2006 - 2009 including floods have significantly affected food production in Nepal (WFP, 2009). Consequences of the adverse impacts of climate change on agriculture have ultimately threatened the food security especially in remote and rural areas where agriculture is mostly depending on nature. Increased variability in precipitation results an increase in drought and flood. The changes in temperature and precipitation pattern also results the changes in the growing period of agricultural crops. Consequently, agriculture sector is likely to change. In the situation of severe effect of climate change, farmers have adopted different adaptation strategies at different places based on their knowledge and experience over the time. Literature indicates that farm households' decisions on adaptation to climate change depend on a range of socioeconomic and physical factors. A study by Tiwari et al. (2014) in three different agro-climatic regions indicated that factors like resource availability, labor availability, farm income, institutional activities, and involvement in community level organizations influences farmers' decisions on adapt the action. It is, in this context that this study on climate changes and its impacts on agriculture is very important so that this paper aims to explore the changing situation of temperature and rainfall based on observed data and people's perception and further explore its effect of agriculture and adaptation strategies adopted by local people of Mangaltar of Khotang district, Nepal.

\section{Methodology}

\section{Data and methods}

The study is based on both primary and secondary data. Climate data from 1960 2009 (42 rainfall stations and 12 temperature stations) of Eastern Nepal were collected from Department of Hydrology and Meteorology (DHM). The field data were collected in 2012. A regional analysis was done using Arc GIS 9.3. The primary and secondary attribute data were entered in Excel and converted into SPSS. Then regression analysis of climate trend was done with the help of SPSS software. 
Primary data on climate change perception, agricultural pattern, and adaptation pattern were collected using PRA methods particularly observations, household (HHs) interview, Key Informant Survey (KII), and Focus Group Discussion (FGD). It was conducted four months field work. Total 60 Household (17 percent) among the 322 Households in the study area was selected randomly for interview. Altogether 15 key informants were interviewed with age over 40 years to collect information on general and specific trends of social, economic and natural environment that explored local perceptions of climate change and variability in the past 40-60 years. An elder person knows a bit more since a long time who is living in a same place. Almost key informants were farmer who is familiar with environment and socioeconomic condition of the area. The survey used a semi-structured questionnaire.

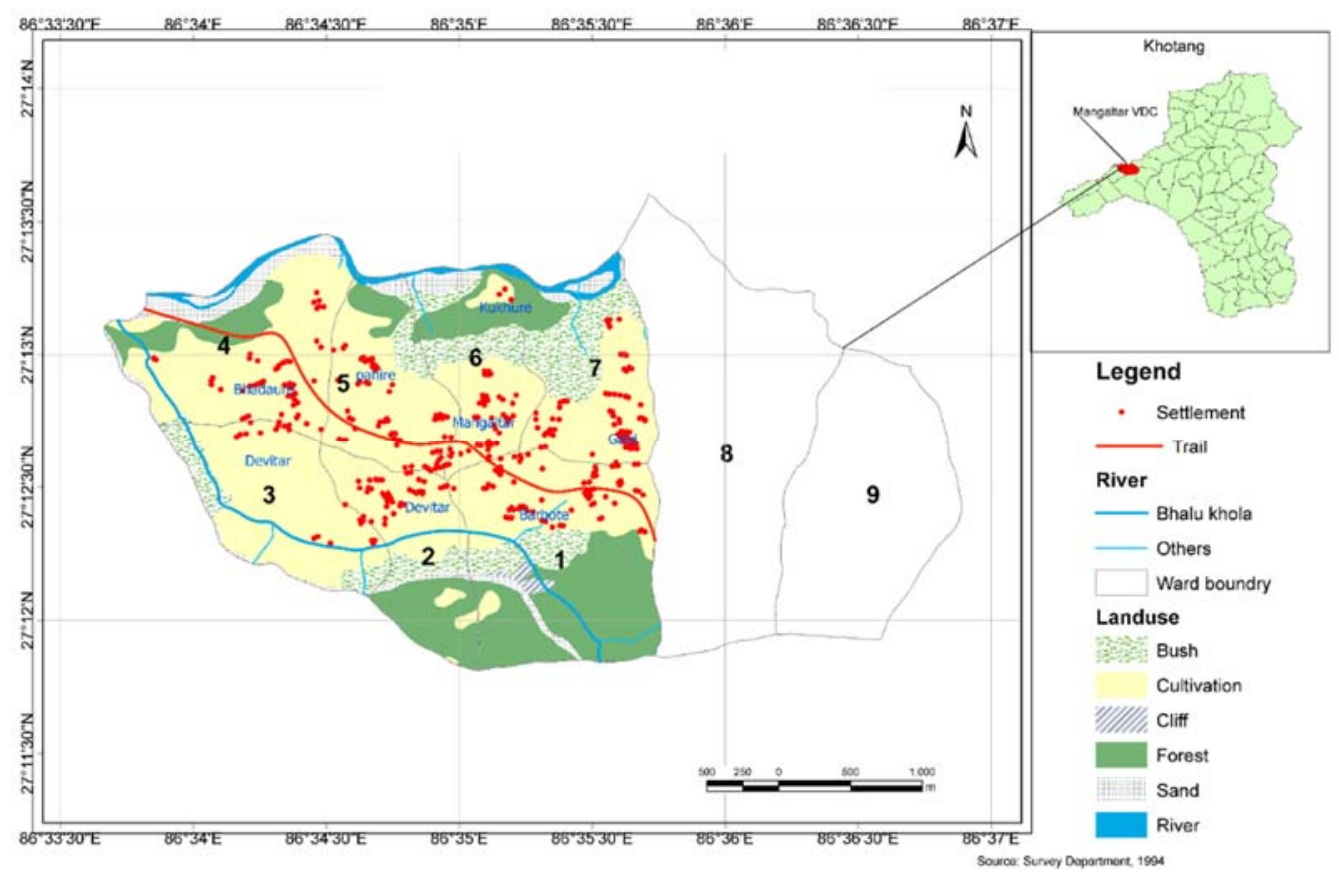

Figure 1: Study area and its drainage and land use distribution

Mangaltar VDC, is one of the 76 VDCs of Khotang district. It is located in between the $27011^{\prime} 56^{\prime \prime}$ - $27013^{\prime} 40^{\prime \prime} \mathrm{N}$ latitude and $88034^{\prime} 30^{\prime \prime}$ - $86036^{\prime} 55^{\prime \prime} \mathrm{E}$ longitude. Total area of the VDC is $11.5 \mathrm{~km} 2$ and altitude ranging from around 400 up to 1200 masl. There are 16 settlements in this VDC. The settlements of Rai ethnic group are located generally on gently sloping terraces. Similarly, Magar settlement is also located in ward no. 4 with little more cluster than other settlements. Most of Chhetri settlements are in sloppy terrain. Chhetri's houses are dispersed but Dalit 
community settlements distributed in agglomeration form. The size of settlements ranges between 10 - 25 households.

\section{Result and discussion}

About $40 \%$ households of the study area are engaged in agricultural activities only. Remaining 60\% households are involved in both farming and other secondary activities. About 65 percent HHs do not produce sufficient food for their annual requirement. Among the insufficient household, 26.7\% HHs have enough for 7 - 9 months, $31.1 \%$ household have for 4 - 6 months, and $6.7 \%$ household have only for 3 months. The number of households is highest in landholding size of $0-0.5$ ha. Almost 52\% HHs does not hold any wet land.

Dudhkoshi, one of the seven branches of the Koshi River, a few streams, i.e. Bhalu khola (Rabu khola) and Dhobi khola are perennial rivers. Local people have not utilized water from Dudhkoshi as it lies in the bottom of the hill. Bhalu khola and Dhobi Rivers are main source of drinking water and are equally important for irrigation purpose.

\section{Observed precipitation trend}

The annual seasonal rainfall trends in Khotang district show decreasing trend in two seasons, i.e., monsoon and post-monsoon rainfall. The pre-monsoon and winter rainfall trends are positive. The average rainfall in eastern development region is about $2500 \mathrm{~mm}$ (MoE, 2011). The analysis of precipitation data from 166 stations by Sharma (2010) revealed an increasing trend in annual rainfall from 1976 to 2005 in eastern development region (EDR). This study also indicates positive trend though annual rainfall in hill region has been insignificantly decreasing trend.

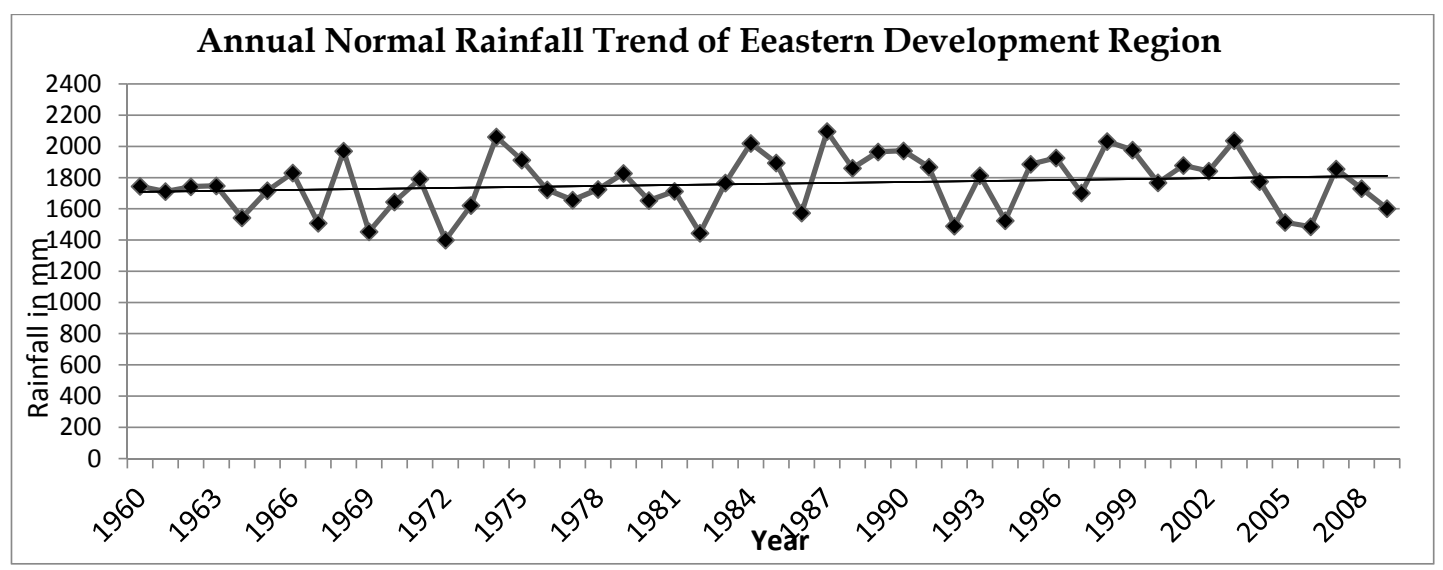

Figure 2: Annual normal precipitation in EDR 
The nearest meteorology station from the study area is Diktel which is located at $1623 \mathrm{~m}$. This data also shows the decreasing trend of annual rainfall.

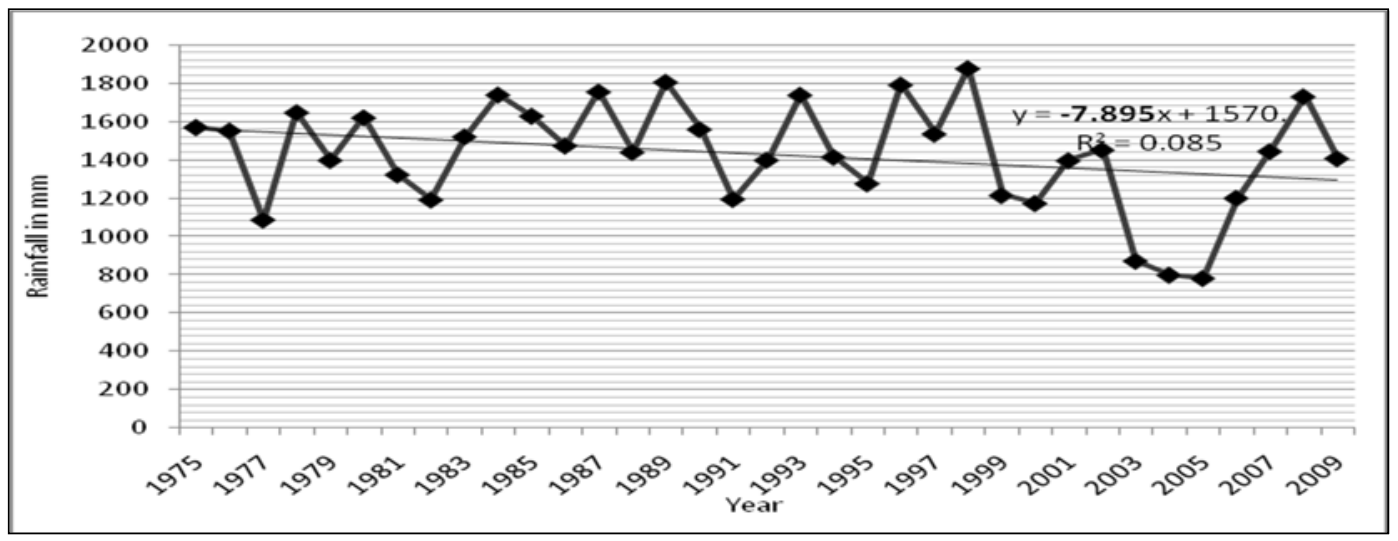

Figure 3. Annual rainfall trend in Diktel, Khotang

Figure 4 presents the spatial distribution of overall rainfall in Khotang district. From the central part to almost upper parts of district have lowest (-7.89 $-5.52 \mathrm{~mm} /$ year) rainfall distribution, the southern part has the highest and the western part where the study area, Mangaltar VDC, is located has $-5.52-0.78 \mathrm{~mm}$ /year rainfall occurs.

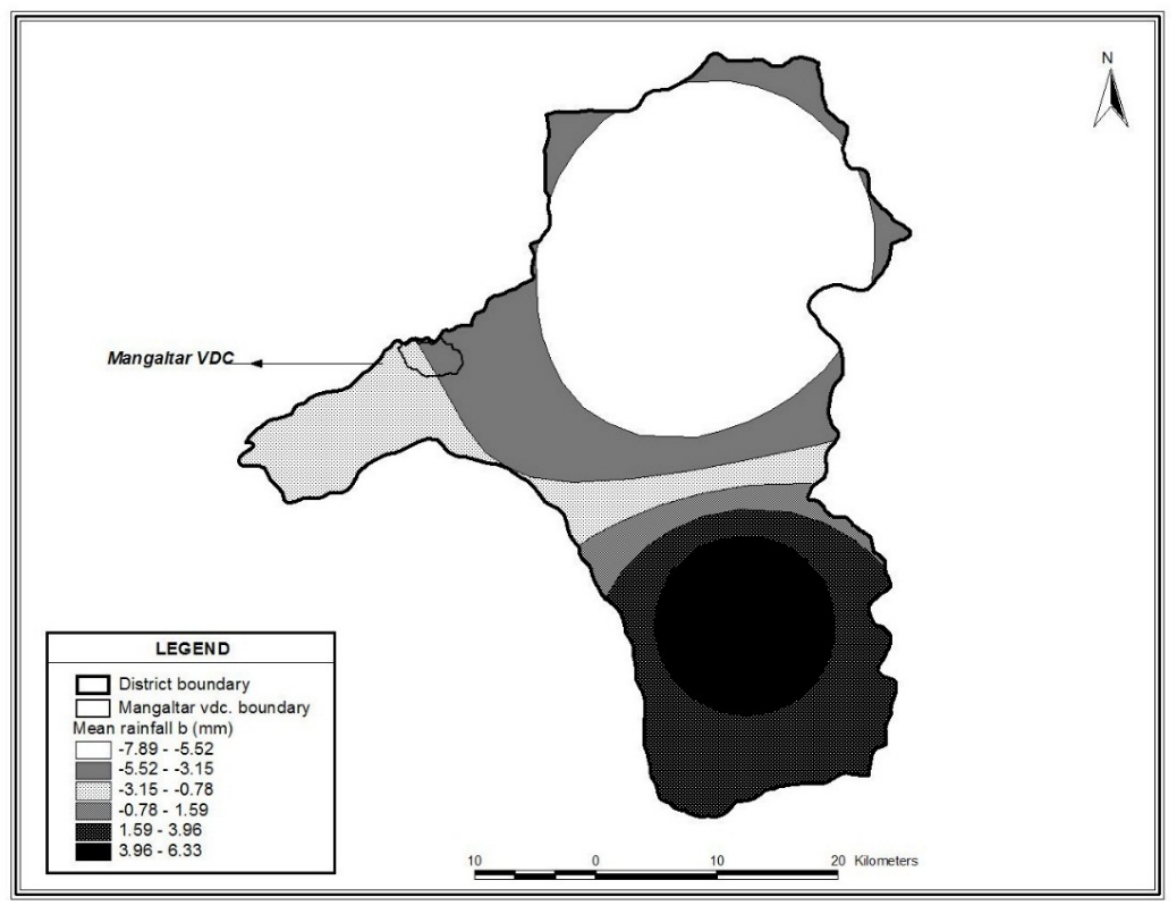

Figure 4: Spatial pattern of annual rainfall trend in Khotang (1960 - 2009) 
The overall annual mean trend of Nepal studied have revealed increasing trend over the 1956 - 2006 by $1.8 \mathrm{~mm}$ /year and this study also shows increasing trend by $2.54 \mathrm{~mm} /$ year in eastern development region. By differently in the Khotang district, the annual mean trend is decreasing by $-2.29 \mathrm{~mm} /$ year but not significantly. Moreover, in Diktel (nearest from the study area), it is significantly decreasing by $7.895 \mathrm{~mm}$ per year. It shows that the trend is decreased at local level unlikely at regional level (Table 1).

Table 1: Summary of rainfall trend (annual change in $\mathrm{mm} /$ year)

\begin{tabular}{|l|l|l|l|l|}
\hline Precipitation & $\begin{array}{c}\text { Eastern Development } \\
\text { Region }\end{array}$ & Eastern Hil & \multicolumn{1}{|c|}{$\begin{array}{c}\text { Khotang } \\
\text { District }\end{array}$} & Diktel \\
\hline Annual & +2.541 & -1.136 & -2.29 & -7.895 \\
\hline Pre-monsoon & +1.362 & +0.65 & +0.399 & +1.665 \\
\hline Monsoon & -0.01 & -1.28 & -2.141 & -3.614 \\
\hline Post-monsoon & -0.77 & -0.793 & -1.022 & -5.759 \\
\hline Winter & -0.34 & +0.337 & +0.329 & -0.324 \\
\hline
\end{tabular}

Source: DHM

\section{Observed temperature trend}

The annual mean temperature trend of eastern development region between 1985 2009 indicates $0.003^{\circ} \mathrm{C}$ per year changes. Similarly, maximum and minimum trends are $0.022^{\circ} \mathrm{C}$ and $-0.013^{\circ} \mathrm{C}$ per year respectively. Likewise, the analysis of data recorded in 14 stations in the eastern Hill region, the annual mean temperature trend shows an increasement by $0.057^{\circ} \mathrm{C}$. Similarly, the maximum and minimum temperature trend is also increasing by $0.173^{\circ} \mathrm{C}$ and $0.004^{\circ} \mathrm{C}$ respectively.

\section{Climate changes perceived by local people}

Attempt has been made to study the perception of 60 local people about climate change and its impact on agriculture based on their experience. Most of the respondents of the study area have been experiencing warming and observing changing rainfall pattern in terms of frequency, magnitude and timing in the study area.

The Table 2 shows the number and percentage of respondents who observed the pattern of monsoon rainfall since long time. It shows that nearly $37 \%$ who have 
experienced of constant and decreasing rainfall frequency and about $27 \%$ have experience of increasing frequency of rainfall occurrence. Likewise, in the case of magnitude, $85 \%$ people have observed decreasing trend and by $15 \%$ have experienced same as before. Out of total, about $57 \%$ respondents observed late monsoon and $43 \%$ have observed same in relation to timing of monsoon rainfall. Similarly, they observed less rainfall in amount and frequency compared to the past.

Table 2: Number of respondents by observed of monsoon rainfall pattern

\begin{tabular}{|l|c|c|c|c|c|c|c|}
\hline \multicolumn{1}{|c|}{ Parameter } & \multicolumn{3}{c|}{ Frequency } & \multicolumn{2}{c|}{ Magnitude } & \multicolumn{3}{c|}{ Timing } \\
\hline Trend & Constant & Decreasing & Increasing & Constant & Decreasing & Constant & Late \\
\hline No. of Respondent & 22 & 22 & 16 & 9 & 51 & 26 & 34 \\
\hline Percentage & 36.7 & 36.7 & 26.6 & 15.0 & 85.0 & 43.3 & 56.7 \\
\hline
\end{tabular}

Source: Field survey, 2012

Regarding to the changes on temperature, nearly $62 \%$ people have experienced more intense hot in summer season and $39 \%$ people have experienced the more intense cold in winter season compared to the past. Nearly $3 \%$ people have experienced less hot for recent years whereas $35 \%$ people have same experience of summer temperature like before. In the case of winter temperature, majority of people have not experienced changes in cold. The response to the starting time of summer season, nearly $31 \%$ have observed early starting, nearly $8 \%$ have observed late while remaining $1 \%$ have experienced no change. Similarly, the respondents who observed the starting time of winter season, 30\% people have observed as early, $19 \%$ people have observed late and $51 \%$ have experienced same as before.

Table 3 shows the people's perception on temperature trends in Mangaltar VDC with observed trends. It has confirmed that the result of observed data and people perception are similar.

Table 3: Comparison between observed and people's perception

\begin{tabular}{|l|l|l|}
\hline Trend & Observed & Experienced \\
\hline Temperature & Increasing & Increasing \\
\hline Maximum & Increasing & Increasing \\
\hline Minimum & Increasing & Constant \\
\hline Mean & Decreasing & Decreasing \\
\hline Precipitation
\end{tabular}




\begin{tabular}{|l|l|l|} 
Pre-monsoon & Increasing & Decreasing \\
\hline Monsoon & Decreasing & Decreasing \\
\hline Post-monsoon & Decreasing & Decreasing \\
\hline Winter & Decreasing & Decreasing \\
\hline
\end{tabular}

Source: DHM and field survey, 2012

\section{Climate change impacts on agriculture}

It has found significant changes and impacts of climate change on agriculture calendar and productivity. Furthermore, there are changes on maize and vegetables cropping pattern, green grass and straw availability, manure transport time and monsoon rainfall time. A respondent of low land says that the thickness of fog is getting thicker for the last 6/7 years. And another one respondent of upland says that he had never seen fog in upland before but recently he is observing in the morning time of winter. Dew is harmful for horse gram and black gram in upper part and north facing slope or shadow area of the VDC. Though, it is beneficial for millet, black gram, potato, and vegetable in the lower part and south facing slope. Similarly, most of the people have been noticing decreasing frequencies of hailstorm for the last 5/6 years. In the past, hailstorm often used to occur with big size and black color. Mist also affects potato, wheat over the period of Jan - March (winter). Due to those effects of dew, some farmers left to cultivate horse gram and black gram for the last few years in the northern and upper part of the study area. The dew is observed little bit more than observed in the past in southern part of ward no 4. Likewise, mist has negative impact on wheat that yield has decreased by $60 \%$. In this way climate variability has affected on crop production (Table $4 \mathrm{a}$ and $4 \mathrm{~b}$ )

\begin{tabular}{|l|l|l|l|l|}
\hline $\begin{array}{l}\text { Table 4a: \% of HHs Stopping } \\
\text { Cultivation by Crops }\end{array}$ & \multicolumn{2}{l|}{$\begin{array}{l}\text { Table 4b: \% of HHs Cultivating } \\
\text { Different Crops }\end{array}$} \\
\cline { 1 - 1 } Crops & Percentage & Crops & Percentage \\
\hline Cotton & 100 & Maize & 100 \\
\hline Millet & 3.3 & Pulses & 100 \\
\hline Horsegram & 6.7 & Millet & 91.7 \\
\hline Soyabean & 1.7 & Summer paddy & 55 \\
\hline Buckwheat & 50 & Winter paddy & 23.3 \\
\hline Sesame & 3.3 & Wheat & 10 \\
\hline
\end{tabular}




\begin{tabular}{|l|l|l|l|l|} 
Wheat & 40 & Winter maize & 3.3 \\
\hline Potato & 10 & Tobacco & 16.7 \\
\hline Maize in khet & 10 & Ghaiya (dry paddy) & 3.3 \\
\hline Barkhe paddy & 16.7 & Vegetables & 28.4 \\
\hline Tobacco & 86.7 & & \\
\hline
\end{tabular}

Source: Field survey, 2012

Because of the late starting of rainfall in maize cropping season, maize production has decreased by 30 - 35 percent. Its production has decreased manly due to strong wind during the flowering time. Since more than a decade, there is not enough water to irrigate paddy field due to decreasing rainfall in pre-monsoon and monsoon season. Second, the available springs sources nearby of paddy field have gradually decreased, and many have dried out. A decade ago, farmers of the upper hill in the study area had cultivated both winter and summer paddy in Bhalukhola river side, since a decade paddy is cultivated only in summer. The Bhalukhola river water volume has also decreased for the last 3 years. About 2 decades ago, there was more volume of water in spring and used to flow out from the well which now dried. Last year many springs became dry in the March - May (pre-monsoon) cause of long drought. Since the half of a decade, some people have started cultivation of millet, junelo (black millet) and maize instead of paddy in the previously paddy field due to lack of irrigation. Different types of impacts and consequences of climate change are given in Table 5.

Table 5: Climate change impacts and consequences

\begin{tabular}{|l|l|l|}
\hline Change/Evidences & \multicolumn{1}{|c|}{ Impact/Change } & \multicolumn{1}{c|}{ Consequences } \\
\hline Late rainfall & Late cropping calendar & $\begin{array}{l}\text { Declination of yield, grass } \\
\text { shortage }\end{array}$ \\
\hline Less rainfall & Cropping pattern change & $\begin{array}{l}\text { Less production, water and } \\
\text { grass shortage, stress for } \\
\text { collecting resources }\end{array}$ \\
\hline Fog & $\begin{array}{l}\text { Increment of cold, dry out } \\
\text { cod of maize and damaging } \\
\text { of potato and grass }\end{array}$ & $\begin{array}{l}\text { Less maize grain and } \\
\text { shortage of grass and health } \\
\text { problem }\end{array}$ \\
\hline Dew & $\begin{array}{l}\text { Difference impact between } \\
\text { two different slope and } \\
\text { altitude for winter crops }\end{array}$ & $\begin{array}{l}\text { Damage horse-gram and } \\
\text { black-gram in northern and } \\
\text { upper part and good }\end{array}$ \\
\hline
\end{tabular}




\begin{tabular}{|c|c|c|}
\hline & & $\begin{array}{l}\text { production in southern and } \\
\text { lower part. }\end{array}$ \\
\hline Mist & Wheat production & $\begin{array}{l}\text { Wheat damage and decrease } \\
\text { yield more than } 50 \text { percent. }\end{array}$ \\
\hline \multirow[t]{3}{*}{$\begin{array}{l}\text { Temperature } \\
\text { increase }\end{array}$} & $\begin{array}{l}\text { Dry out and Problem for } \\
\text { man and animal, }\end{array}$ & $\begin{array}{l}\text { Difficulties to collect } \\
\text { resources, lack of grass and } \\
\text { firewood, high pressure and } \\
\text { stress for women, health } \\
\text { problem on men and } \\
\text { animals. }\end{array}$ \\
\hline & Mosquito increase & $\begin{array}{l}\text { sickness, expense money for } \\
\text { mosquito net }\end{array}$ \\
\hline & Insect on mango, & $\begin{array}{l}\text { Mango fruit damage, Loss } \\
\text { income and vitamin }\end{array}$ \\
\hline $\begin{array}{l}\text { Appearance of } \\
\text { new species } \\
\text { (Banmara and Tite } \\
\text { jhar) }\end{array}$ & $\begin{array}{l}\text { Destroy crops and fodder } \\
\text { grass }\end{array}$ & $\begin{array}{l}\text { Lacking or shortage of grass, } \\
\text { loss of productivity. }\end{array}$ \\
\hline
\end{tabular}

Source: Field survey, 2012

There are notably changes in seed varieties. For instance, in the study area 57 percent people have used new variety of maize seed and other crops which is summarized in Table 6. Local people changed the new varieties which were more drought resistance and higher productivity. It has been explained more in adaptation strategy.

\section{Adaptation strategy on cropping}

As a study by the Mountain Research and Development (2016) shows a result on strategies for improving adaptive capacity that farming practices need be adapted to changing phenomenal patterns of crops and crop pests, local people have adopted different adaptation strategies to climate change impact. For instance, local farmers have changed the paddy, maize and millet seeds. For paddy they introduced some varieties, like, Thapachini and Jamare is that type of variety which can produce even in less water. Rosikhole can be harvested before 15 days than Thapachini. Since introduced new seeds Thapachini and Jamare, it could be possible to practice two paddy crops in a year. They have practiced another one named Dipo which have more productivity than previous one. Likely that for winter, they have started Jamare, variety which is also demands less water. 
Table 6: Changes in seed varieties used by local farmer

\begin{tabular}{|c|c|c|c|c|c|c|c|}
\hline \multicolumn{2}{|c|}{ Maize } & \multicolumn{2}{|c|}{ Summer Paddy } & \multicolumn{2}{|c|}{ Winter Paddy } & \multicolumn{2}{|c|}{ Millet } \\
\hline $\begin{array}{c}\text { Past } \\
\text { (before 1975) }\end{array}$ & Present & Past & Present & Past & Present & Past & Present \\
\hline Chepti & $\mid \begin{array}{l}\text { Sano seti } \\
(1975 / 76)\end{array}$ & $\begin{array}{l}\text { Thapachini } \\
(1970 / 71)\end{array}$ & \begin{tabular}{|l} 
Kazasar \\
$(2000 / 01)$
\end{tabular} & \multirow{7}{*}{$\begin{array}{l}\text { Thapachini } \\
\text { (traditional) }\end{array}$} & \multirow{7}{*}{$\begin{array}{l}\text { Jamare } \\
(1993 / 94)\end{array}$} & \begin{tabular}{|l} 
Dalle \\
(traditional)
\end{tabular} & $\begin{array}{l}\text { Nangkatuw } \\
\text { a (1975/76) }\end{array}$ \\
\hline Sathiya & $\begin{array}{l}\text { Sarlahi } \\
(1977 / 78)\end{array}$ & \begin{tabular}{|l} 
Rambilas \\
$(1990 / 91)$
\end{tabular} & & & & \multirow{6}{*}{$\begin{array}{l}\text { Thulo } \\
\text { kodo } \\
\text { (traditional) }\end{array}$} & \begin{tabular}{|l} 
Bikase \\
$(1983 / 84)$
\end{tabular} \\
\hline \multirow{5}{*}{$\begin{array}{l}\text { Acchame } \\
\text { Paheli }\end{array}$} & \begin{tabular}{|l} 
Deuti \\
$(1982 / 83)$
\end{tabular} & \begin{tabular}{|l} 
Dipo \\
$(2000 / 01)$
\end{tabular} & & & & & $\begin{array}{l}\text { Acchame } \\
(1988 / 89)\end{array}$ \\
\hline & \begin{tabular}{|l} 
Taichin \\
$(1988 / 89)$
\end{tabular} & & & & & & \multirow{4}{*}{$\begin{array}{l}\text { Jhakri } \\
(1996 / 97)\end{array}$} \\
\hline & \begin{tabular}{|l} 
Malile \\
$(1995 / 96)$
\end{tabular} & $(2005 / 06)$ & $\begin{array}{l}\text { Manamure } \\
(2002 / 03)\end{array}$ & & & & \\
\hline & \begin{tabular}{|l} 
Pahelo \\
$(1998 / 99)$
\end{tabular} & \multirow[t]{2}{*}{$(2008 / 09)$} & & & & & \\
\hline & \begin{tabular}{|l} 
Bikase \\
$(2000 / 01)$
\end{tabular} & & & & & & \\
\hline
\end{tabular}

Source: Field survey, 2012

Similarly, for maize, they introduced different varieties. They introduced a new variety named Makawanpure which resists to increasing effect of diseases. Another variety which is introduced by villagers is Sarlahi, which has big size grain and cod and grain. It is also draught resistant variety. The other newly introduced variety is Malile, as it yields higher and better for fodder. The newer variety is Sathiya. It has shorter plant ad short growing season (60 days). Likewise, they adopted hybrid variety of millet with the reason of good production.

Furthermore, they have started some different ways of crops production such as weeding, transplanting etc. It has starting transplanting millet in maize field before harvesting maze as they used to do it after harvesting maize in the past. It is mainly due to late rainfall that delayed maize harvesting. It is thus weeding, and sowing time has also delayed.

In the condition of less rainfall and lack of irrigation for paddy transplantation, they sow millet, Junelo (black millet), maize in the paddy field. If winter season became 
drier and produce less, farmers sow buckwheat. If there is draught during maize sowing, as it was in 2012 (2069), they sowed maize almost after the maize season intending to get animal fodder. The same practiced was adopted in the extreme droughts of 1977, 1978, 2011 and 2012 (2034, 035, 068, 069 B.S.). Figure 5 summarizes the adaptation strategies of the local farmers of the study area.

Figure 5: Summarized of adaptation strategies by local people

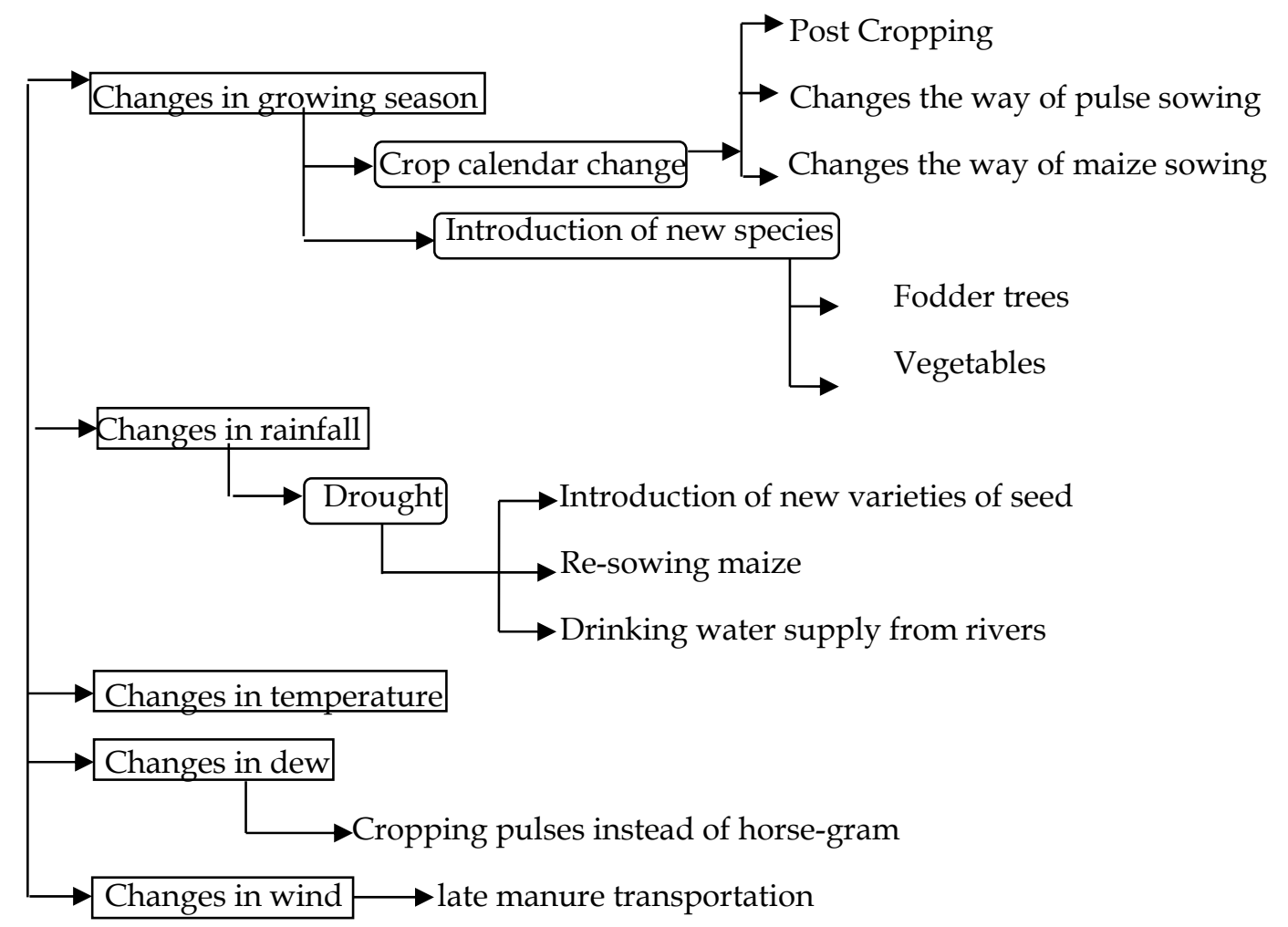

\section{Conclusion}

The analysis of rainfall data during 1960 - 2009 has indicated that annual mean precipitation has increased by $2.541 \mathrm{~mm}$ per year in the eastern development region, whereas Khotang district has been experiencing decreasing annual mean precipitation by $-2.29 \mathrm{~mm}$ per year. Likewise, the annual mean precipitation decreased in Hill region and, also in the study area by -1.136 and -7.895 respectively. Annual mean discharge in Dudhkoshi River (Rabuwabaazar) which is snow-fed river and in the rain-fed river such as Shabhaya Khola has shown an increasing trend. However, the maximum discharge in snow-fed river is increasing and it has observed decreasing trend in rain-fed river. 
Local people have been experiencing changes in rainfall pattern such as decreased frequency of intense rainfall, decreasing winter rainfall, its frequency. It has also experienced decreases in amount of snowfall, dew, fog, hailstorm, frost, prolonged drought and increased temperature. Consequently, it has been observing decreased crop productivity, drying up water sources, decreased fodder production. The agricultural practice of the study area is traditional subsistence farming. Due to very high precipitation variability, poor soil and inadequate farming inputs agricultural productivity is low and it has been decreasing. Local people have been adapting indigenous ways or techniques with the changing environment. Those adaptation measures range from change in the timing of cropping and agricultural operation system. They have adopted drought resistant seed varieties. Similarly, they have adopted new seeds of maize, paddy and fodder tree species and grass species. Some people have replaced some crops like horse grams with millet so that they could grow grass for animal feeding. Because of increased variability in precipitation combined with the changes in migration pattern some previously cultivated land been abandoned, and they left to cultivate a few crops due to wild animals (eg. monkey), and diseases.

\section{Reference}

CBS (2011). Agriculture census 2011 (Summary). Government of Nepal, National Planning Commission, Central Bureau of Statistics. Retrieved from http://cbs.gov.np/sectoral_statistics/agriculture/agriculture_summary

DHM, (2017). Observed climate trend analysis in the districts and physiographic regions of Nepal (1971-2014). Department of Hydrology and Meteorology, Kathmandu

Economic survey, 2017/18. Government of Nepal, Ministry of Finance retrieved from https://mof.gov.np/en/archive-documents/economic-survey-21.html.

MoE. (2010). National adaptation programme of action (NAPA) to climate change. Government of Nepal, Ministry of Environment, Singh Durbar, Kathmandu, Nepal, September 2010.

MoF (2018). Economic survey, 2017/18. Ministry of Finance, Government of Nepal. Kathmandu.

Tiwari KR, Rayamajhi S, Pokharel RK, Balla MK (2014) Determinants of the climate change adaptation in rural farming in Nepal Himalaya. Int J Multidiscip Curr Res 2(1):234-240

WFP (2009). WFP Nepal - Food for thought Series Issue 2, December 2009: the future of food - creating sustainable communities through climate adaptation. World Food Program (WFP-Nepal). 